\title{
Determinants Influencing Consumers Purchasing Intention for Sustainable Fashion: Evidence from Ho Chi Minh City
}

\author{
Thuy Thi Hai HO', Trinh Ngoc Phuong VU², Hieu Minh VU \\ Received: August 01, 2020 Revised: October 05, 2020 Accepted: October 15, 2020
}

\begin{abstract}
This paper investigates factors impacting on sustainable fashion buying intention of consumers by reviewing studies about the topic and conducting a survey with consumers in Ho Chi Minh City. In detail, firstly, an interview with 15 respondents was conducted to check the understanding of concepts and questions and, secondly, the study used the convenient sampling method, with 172 samples collected and analyzed, of which young respondents accounted for the majority of the sample. The respondents tend to go shopping many times in a year, with the number of people buying fashion products from every week to every two months accounting for $65.2 \%$ totally. The findings suggest that the firms should prioritize strategies that can improve customer attitude toward sustainable fashion, making them feel good, pleasant, satisfied and favorable when engaging in sustainable fashion consumption. This study concludes that consumers need more information to enable them to make better ethical decisions. This study proposes that the major channels that consumers use to seek sustainable product information include public education, peer influence, and corporate marketing information about the products. This study concludes that public education and corporate marketing information on green consumption education is effective for improving consumer sustainable buying intention.
\end{abstract}

Keywords: Buying Intention, Sustainable Development, Sustainable Fashion, Ho Chi Minh City, Vietnam

JEL Classification Code: M10, Q01, O10

\section{Introduction}

The United Nations Conference on Trade and Development (UNCTAD) in 2019 noted that apparel production is the second most polluting industry in the world by generated amount of wastewater and emissions (United Nations, 2019). This is a result of 'fast fashion' growth leading to high environmental costs stemming from high demand for water (McKinsey, 2017). The characteristics of

${ }^{1}$ First Author. Foreign Trade University, Ho Chi Minh City campus, Vietnam. Email: hothihaithuy.cs2@ftu.edu.vn

${ }^{2}$ Foreign Trade University, Ho Chi Minh City campus, Vietnam.

Email: phuongtrinhlhp1316@gmail.com

${ }^{3}$ Corresponding Author. Faculty of Business Administration, Van Lang

University, Ho Chi Minh City, Vietnam [Postal Address: 45 Nguyen

Khac Nhu, Co Giang Ward, District 1, Ho Chi Minh City, 700000,

Vietnam] Email: hieu.vm@vlu.edu.vn

(c) Copyright: The Author(s)

This is an Open Access article distributed under the terms of the Creative Commons Attribution Non-Commercial License (https://creativecommons.org/licenses/by-nc/4.0/) which permits unrestricted non-commercial use, distribution, and reproduction in any medium, provided the original work is properly cited. the fast fashion business mentioned include inexpensive and low-quality garments, short-time production and sale, and high-volume consumption, and then fashion products, which are produced under this model often end up in the landfill (Flynn, 2014). In textile manufacturing, pollution comes from chemical treatment used in dyeing and dye preparation, and the scale of landfill formed during treatment (Global Fashion Agenda, 2017; ).

Vietnam is facing urgent pollution problems in relation to water resources of which the garment industry is one of the contributors (Anh, 2019). As of 2017, Vietnam had approximately 7,000 textile enterprises, of which 5,101 enterprises processed garments (accounting for 85\%); 780 enterprises manufacture cloth and dyed cloth (accounting for $13 \%$ ); and 119 enterprises produce cotton and fiber (accounting for 2\%) (Hung, 2019). Therefore, the amount of chemicals used in textile enterprises is about $500-2,000 \mathrm{~kg} /$ ton of product (Hung, 2019). Because of the negative effects of "fast fashion" on the environment, "sustainable fashion" was born as a commitment to the sustainable development of the future fashion industry, linking the fashion industry with green technology and environment friendliness. Many 
international fashion brands such as H\&M, Nike, Marks $\&$ Spencer, Timberland, Burberry, Adidas, and others have recently taken actions through engagement in sustainable fashion by launching collections using recycled materials, developing biological textile production, focusing on ecomaterials, and reducing carbon emission in distribution.

According to Nielsen (2018), sales of sustainable products make up $22 \%$ of the total store retail in the US and they are expected to make up $25 \%$ of store sales in 2021 . A concerned topic is how to increase the share of sustainable products on the market. As a consequence, it is necessary for firms to conduct strategies to influence consumers into buying behavior toward sustainable products. In addition, in the literature, there have been many studies on consumer behavior toward environmental friendly products, but few of them have investigated the green shopping behavior toward fashion. Nonetheless, these studies mainly focus on green fashion, slow fashion or ethical fashion instead of sustainable fashion. They use these terms interchangeably as a common meaning instead of distinguishing them with different characteristics. Similarly, though Vietnamese consumers are reported to be the most socially conscious in the Asia-pacific area (Nielsen, 2015) and the studies on sustainable consumption, in general, and that toward fashion, in particular, are limited (Hung et al., 2018; Tri \& Linh, 2018; Nguyen et al., 2020).

Therefore, this paper aims to investigates the factors influencing consumers' intention to purchase sustainable fashion products in Ho Chi Minh City, to contribute to the existing theory regarding the similar context and also hope to help enterprises in fashion industry, and sustainable fashion manufacturers especially, to implement strategies to stimulate consumer demand on sustainable products, thereby indirectly moving toward the sustainable development of society.

\section{Literature Review}

\subsection{Sustainable Development and Sustainable Fashion}

The term "sustainable development" was officially introduced in the Brundtland Report by UNWCED (1987) as "meeting the needs of the present without compromising the ability of future generations to meet their needs" (Brundtland, 1985), recognizing the interdependence of environmental, social and economic systems as the principles for sustainable development rigor and promotes equality and justice through people empowerment and a sense of global citizenship. Economic growth requires the full use of resources, so that individuals can maintain a reasonable standard of living, while avoiding social and environmental damage. As the environmental awareness of consumers increases, and sustainable development becomes more and more crucial for businesses, it also plays an important role in the concern of fashion businesses. Engagement in sustainable fashion improves companies' image, achieves a wider range of consumers and gains competitive advantages in the market (Faisal, 2010; Yang et al., 2010), as a result, it attract much attention of firms in the area of textile (Morana \& Seuring, 2011).

Though there is not an universally-accepted definition of sustainable fashion, it can be defined as "the use of clothing for purposes, which are beyond utilitarian needs, including "identity making", and are achieved without jeopardizing the ability of future generations to meet their needs" (EderHansen et al., 2012). To reach sustainability in fashion, key sustainability strategies will include the use of organic fibers, reuse and recycling of materials, reuse of antique and used goods, and cleaner production technology (Caniato et al, 2010). Similarly, Gwozdz et al. (2013) suggest it must include demands for sustainable alternatives, choice of environmentally-friendly garments, which can be cold washed and easily dried, as well as able to recycled and responsibly disposed of. Moreover, to achieve positive changes, all attendees must contribute, from fashion manufacturers to consumers (Caniato et al., 2010). Sustainable fashion requires a sustainable supply chain including eco-material preparation, sustainable manufacturing, green distribution and retailing, as well as ethical consumers (Shen et al, 2014).

\subsection{Knowledge of Environmental Issues and Subjective Norm}

Many researchers stated that consumer knowledge of environmental issues is an important indicator for consumer purchasing intention of environmentally-friendly products (Pagiaslis \& Krontalis, 2014; Yadav \& Pathak, 2016; Lee \& Lim, 2020). Ellen et al. (1991) argue this positive relationship come from people who have better environmental knowledge and are likely to pay more contribution to solving environmental issues than those who have less environmental knowledge. This argument is supported by Singh and Gupta (2013). The subjective norm is "perceived social pressure to perform or not perform the behavior" (Ajzen, 1987), which is assumed consumers have a normative belief that a certain behavior is accepted or not and these shape their perception of the behavior and, then, determine their intention to or not to embrace the behavior. For example, when customers see green purchasing behavior as important, they are more likely to accept these behaviors (Paul et al, 2015). Supporting this assumption, Ham et al. (2015) suggest subjective norms are an important factor to consumer-buying intention in terms of green food purchase, in particular. Also, other scholars (Vermeir \& Verbeke, 2008; Chen, 2007) point out a positive relationship between the subjective norms and the intention to buy organic and sustainable food. In term of sustainable apparel consumption, Weiner (2017) finds that subjective 
norms impact purchase intention, whereas, other researchers (De Lenne \& Vandenbosch, 2017; Tri \& Linh, 2018) affirms it is not a significant predictor of the buying intention.

\subsection{Knowledge of Sustainable Fashion and Attitude Towards Sustainable Fashion}

Consumer knowledge is known as the combination of the familiarity, which refers to experiences a consumer has with the product and product knowledge that refers to total information stored in that one's memory (Philippe \& Ngobo, 1999). Individual's knowledge plays an important role in sustainable consumption behavior (especially fashion). If consumers are more aware of the impact of clothing, they are more likely to buy sustainably. Kang et al. (2013) confirm a positive correlation between consumer perceptions in buying intention for sustainable clothing, namely, organic cotton. They also express that, if consumers knew more about sustainability, they would be more likely to buy products made from organic cotton. In contrast, Wolsink (2007) notes a relationship between environmental knowledge and green purchase intention does not exist. Attitude is the extent to which an individual has favorable or unfavorable opinion on a behavior (Ajzen, 1991).

Research has shown that a positive attitude often leads to positive buying intentions (Pavlou, \& Fygenson, 2006; Chen \& Tung, 2014; Nguyen et al., 2019). In the context of sustainable consumption, specifically for fashion, research by Lenne and Vandenbosch (2017); Kong et al. (2016); Diddi and Niehm (2016) identify a positive relationship between the two factors. In addition, the accessibility and affordability of sustainable clothing is one of the major obstacles consumers face when attempting to buy eco-friendly and ethical clothing due to insufficient stores and limited choices in style, and size (Connell, 2010). For similar designs, sustainable or ethical clothes have higher price compared to the popular ones, thereby discouraging low-income buyers to conduct their buying intention for the products (Hines \& Swinker, 1996; Hustvedt \& Dickson, 2009). Based on the reviewed studies, the following hypotheses are suggested.

H1: Consumer's knowledge of environmental issues positively affects the purchasing intention toward sustainable fashion products

H2: Subjective norms positively affect the purchasing intention toward sustainable fashion products

H3: Consumers' knowledge of sustainable fashion positively affects the purchasing intention toward sustainable fashion

H4: The more favorable attitude towards sustainable fashion a consumer has, the higher his/her purchasing intention for sustainable fashion is.

H5: Accessibility and affordability positively affects the purchasing intention toward sustainable fashion.
In term of measurement, the study adapts scales from previous studies, with some changes made in the wording to better fit the current research context.

\section{Research Methodology}

Data collection contains two phases; the first phrase is a preliminary focus group of 15 random respondents to check their understandings of the concepts and clarify the questions unclear to the respondents. In the second phase, a survey was distributed online and offline from October 25 to November 8, 2019, to 270 consumers residing in Ho Chi Minh City, selected by a random sampling method. After filtering the invalid responses, 172 valid responses have been collected for the analysis. According to Tabachnick and Fidell (2007), the minimum sample size for optimal variable regression analysis is $\mathrm{N} \geq 8 \mathrm{k}+50$, where $\mathrm{k}$ is the number of independent variables. Thus, the proposed research model with five independent variables, and a sample size of 172 , greater than $5.5+50=$ 75 is appropriate. The data has been processed by SPSS 20.0 software. Also, descriptive analyses are done to identify respondents' demographic profile. Later, the scales of variables were verified by Cronbach's Alpha analysis. EFA and multiple regression analysis have been done to identify factors impacting consumer purchasing intention toward sustainable fashion.

\section{Results and Discussions}

\subsection{Descriptive Statistics}

Regarding the age group, the majority of the respondents were 20-24 years old (44.2\%), followed by those under the age of 20. In terms of fashion purchasing frequency, respondents tend to go shopping many times in a year, with the number of people buying fashion products from every week to every two months accounts for $65.2 \%$ of the total.

\subsection{Cronbach's Alpha Coefficient Analysis}

The Cronbach's Alpha coefficient analysis has been done in three stages. After the first analysis, some observations have been deleted to increase the credibility for the measures as KSF3 (with Cronbach's Alpha if item deleted $=0.886>$ Cronbach's Alpha $=0.840$ ); AA2 (with Cronbach's Alpha if item deleted is $0.582>$ Cronbach alpha $=0.530$ ) and PIS5 (with Cronbach's Alpha if item deleted is $0.929>$ Cronbach alpha $=0.902)$. In the second analysis, two more observations have been deleted as KSF4 and AA1 (Cronbach's Alpha if item deleted values of $0.892>$ Cronbach's Alpha of KSF = 0.886 and $0.677>$ Cronbach's Alpha of AA $=0.582$ ). In the third analysis, all of Cronbach's Alpha values are greater than 0.6, and values of Corrected Item-Total Correlation are greater than 0.3 and ensure a good level of reliability. 
Table 1: Measurement development

\begin{tabular}{|c|c|c|}
\hline Coding & Items & Source(s) \\
\hline \multicolumn{3}{|c|}{ Construct: Subjective norm } \\
\hline SN1 & Most of my friends and family members share my views about sustainable fashion. & \multirow{3}{*}{$\begin{array}{l}\text { Yamoah, Duffy, } \\
\text { Petrovici, and } \\
\text { Fearne (2016) }\end{array}$} \\
\hline SN2 & My decision to buy sustainable fashion is influenced by my friends and family. & \\
\hline SN3 & The views of other people that I respect influence my decision to buy sustainable fashion. & \\
\hline \multicolumn{3}{|c|}{ Construct: Knowledge of environmental issues } \\
\hline KEI1 & Air pollution can occur during some common dye processes of textiles. & \multirow{3}{*}{$\begin{array}{l}\text { Diddi and } \\
\text { Niehm (2016) }\end{array}$} \\
\hline $\mathrm{KEI} 2$ & $\begin{array}{l}\text { Chemical pollutants are produced during manufacturing of synthetic or manufactured fibers } \\
\text { such as polyester }\end{array}$ & \\
\hline KEI3 & Textile dyeing and finishing processes use a lot of water. & \\
\hline $\mathrm{KEI} 4$ & Supporting sustainable products could be a beneficial investment in long term & Suki (2016) \\
\hline \multicolumn{3}{|c|}{ Construct: Knowledge of sustainable fashion } \\
\hline KSF1 & I am familiar with the term sustainable fashion & \multirow{4}{*}{ Preuit (2016) } \\
\hline KSF2 & I know where to purchase fast fashion apparel & \\
\hline KSF3 & I know about the environmental impacts of sustainable fashion apparel & \\
\hline KSF4 & I have often read articles or news about sustainable fashion apparel. & \\
\hline \multicolumn{3}{|c|}{ Construct: Accessibility and Affordability } \\
\hline AA1 & Sustainable fashion can be found in different varieties of colors, shapes, designs and sizes. & \multirow{4}{*}{ Sadiku (2017) } \\
\hline AA2 & I check prices even on the smallest items before purchase & \\
\hline AA3 & I can afford to buy sustainable clothing even when it is relatively more expensive & \\
\hline AA4 & Sustainable fashion products are available in my city & \\
\hline \multicolumn{3}{|c|}{ Construct: Attitude toward sustainable fashion } \\
\hline ASF1 & I think that engaging in sustainable fashion is good & \multirow{5}{*}{$\begin{array}{c}\text { Sparks and } \\
\text { Shepherd } \\
\text { (1992). }\end{array}$} \\
\hline ASF2 & I think that engaging in sustainable fashion is wise & \\
\hline ASF3 & I think that engaging in sustainable fashion is pleasant & \\
\hline ASF4 & I think that engaging in sustainable fashion is satisfying & \\
\hline ASF5 & I think that engaging in sustainable fashion is favorable & \\
\hline \multicolumn{3}{|c|}{ Construct: Purchasing intention toward sustainable fashion } \\
\hline PIS1 & I would buy sustainable clothing to help support sustainable production & \multirow{5}{*}{ Gam (2011) } \\
\hline PIS2 & If available, I would seek out sustainable fashion & \\
\hline PIS3 & I am likely to purchase sustainable fashion & \\
\hline PIS4 & I am willing to buy an sustainable fashion product & \\
\hline PIS5 & Whenever possible, I buy clothing I consider sustainable fashion & \\
\hline
\end{tabular}

After Cronbach's Alpha analysis, EFA has been conducted and results show that sig Bartlett's Test $=0.000$ $<0.05$ and $0.5<\mathrm{KMO}=0.764<1$ indicating the suitability for factor analysis. However, after the first rotation, SN1 has factor loading $<0.5$, hence eliminated from the study. Moreover, ASF2 does not converge with other ASF variables in the same group but joins with KEI factors. To ensure consistency about meaning for ASF variables, ASF2 is deleted. Then the second EFA is conducted after that. The results of $2^{\text {nd }}$ EFA show that, sig. Bartlett's Test $=0.000$ $<0.05$, and $\mathrm{KMO}$ index is $0.5<\mathrm{KMO}=0.744<1$, proving appropriation for factor analysis. Moreover, results of factor analyses show that factors' eigenvalues are all greater than 1, therefore no variable is eliminated. All 14 remaining items of the independent variables have factor loadings greater than 0.5 , and they are classified into four groups of factors, where the "Knowledge of Sustainable Fashion" and "Accessibility and Affordability" are combined into one factor. 
Table 2: The $3^{\text {rd }}$ Cronbach's Alpha

\begin{tabular}{|c|c|c|c|c|}
\hline Items & $\begin{array}{c}\text { Scale Mean if Item } \\
\text { Deleted }\end{array}$ & $\begin{array}{c}\text { Scale Variance if Item } \\
\text { Deleted }\end{array}$ & $\begin{array}{c}\text { Corrected Item-Total } \\
\text { Correlation }\end{array}$ & $\begin{array}{l}\text { Cronbach's Alpha if } \\
\text { Item Deleted }\end{array}$ \\
\hline \multicolumn{5}{|c|}{ Subjective Norm: Cronbach's Alpha = 0.681} \\
\hline SN1 & 6.012 & 4.573 & 0.417 & 0.678 \\
\hline SN2 & 5.779 & 3.565 & 0.598 & 0.444 \\
\hline SN3 & 5.535 & 3.712 & 0.479 & 0.611 \\
\hline \multicolumn{5}{|c|}{ Knowledge of environmental issues: Cronbach's Alpha $=0.800$} \\
\hline KEI1 & 5.953 & 5.401 & 0.609 & 0.751 \\
\hline KEI2 & 5.953 & 5.214 & 0.649 & 0.731 \\
\hline KEI3 & 5.860 & 5.361 & 0.620 & 0.746 \\
\hline KEI4 & 6.302 & 5.639 & 0.571 & 0.769 \\
\hline \multicolumn{5}{|c|}{ Knowledge of sustainable fashion: Cronbach's Alpha = 0.892} \\
\hline KSF1 & 3.453 & 1.232 & 0.804 & \\
\hline KSF2 & 3.233 & 1.209 & 0.804 & \\
\hline \multicolumn{5}{|c|}{ Accessibility and Affordability: Cronbach's Alpha $=0.677$} \\
\hline AA3 & 3.267 & 1.320 & 0.513 & \\
\hline AA4 & 2.779 & 1.109 & 0.513 & \\
\hline \multicolumn{5}{|c|}{ Attitude toward sustainable fashion: Cronbach's Alpha $=0.830$} \\
\hline ASF1 & 8.872 & 8.978 & 0.614 & 0.799 \\
\hline ASF2 & 8.756 & 9.706 & 0.559 & 0.814 \\
\hline ASF3 & 8.628 & 8.235 & 0.732 & 0.764 \\
\hline ASF4 & 8.442 & 8.856 & 0.543 & 0.822 \\
\hline ASF5 & 8.884 & 8.478 & 0.703 & 0.773 \\
\hline \multicolumn{5}{|c|}{ Purchasing intention toward sustainable fashion: Cronbach's Alpha = 0.929} \\
\hline PIS1 & 6.942 & 7.985 & 0.801 & 0.919 \\
\hline PIS2 & 7.081 & 7.678 & 0.879 & 0.894 \\
\hline PIS3 & 6.919 & 8.005 & 0.849 & 0.904 \\
\hline PIS4 & 6.965 & 7.472 & 0.818 & 0.915 \\
\hline
\end{tabular}

Theses items (KSF2, KSF1, AA3, AA4) mainly mention whether an individual has the ability to approach sustainable fashion or not, including the information communication about the product concept (I am familiar with the term sustainable fashion), the product price (I can afford to buy sustainable clothing even when it is relatively more expensive) and the product distribution (I know where to purchase fast fashion apparel; sustainable fashion products are available in my city). According to Carrigan and Attalla (2001), though consumers today are more aware of environmental issues as well as the importance to support the sustainability by adopting sustainable consumption, this awareness may not lead to the increase in consumer buying intention toward the related products because of the uncertainty about which companies and products are environmentally-friendly and the ability to access the products in term of price and distribution (Boulstridge \& Carrigan, 2000; Zadek et al., 1998). Therefore, the more consumers are able to approach sustainable fashion, the more they are likely to buy the products. H3 is posited as the following:

H3: Consumers' ability to approach sustainable fashion (AB) positively affects the purchasing intention toward sustainable fashion.

In term of the dependent variables, the results of EFA analysis show that sig Bartlett's Test $=0.000<0.05$ and 0.5 $<\mathrm{KMO}=0.848<1$, hence the variable is suitable for factor analysis. With Cronbach's Alpha $=0.929$ and all of the four items have no factor loading less than 0.5 , the results show the correlation between the observed dependent variable and the items. 
Table 3: Factor analysis for independent variables

\begin{tabular}{|c|c|c|c|c|c|}
\hline \multirow{2}{*}{ Factors } & \multirow{2}{*}{ Items } & \multicolumn{4}{|c|}{ Factor loading } \\
\hline & & 1 & 2 & 3 & 4 \\
\hline \multirow{4}{*}{$\begin{array}{l}\text { Ability to approach sustainable } \\
\text { fashion }\end{array}$} & KSF2 & 0.871 & & & \\
\hline & KSF1 & 0.864 & & & \\
\hline & AA4 & 0.750 & & & \\
\hline & AA3 & 0.619 & & & \\
\hline \multirow{4}{*}{ Attitude toward sustainable fashion } & ASF3 & & 0.861 & & \\
\hline & ASF4 & & 0.746 & & \\
\hline & ASF5 & & 0.740 & & \\
\hline & ASF1 & & 0.616 & & \\
\hline \multirow{4}{*}{ Knowledge of environmental issues } & KEI2 & & & 0.858 & \\
\hline & KEl1 & & & 0.772 & \\
\hline & KEI3 & & & 0.694 & \\
\hline & KEI4 & & & 0.629 & \\
\hline \multirow{2}{*}{ Subjective Norms } & SN3 & & & & 0.84 \\
\hline & SN2 & & & & 0.796 \\
\hline Cronbach's Alpha & & 0.829 & 0.814 & 0.800 & 0.611 \\
\hline
\end{tabular}

The hypotheses are adjusted and illustrated in proposed model below:

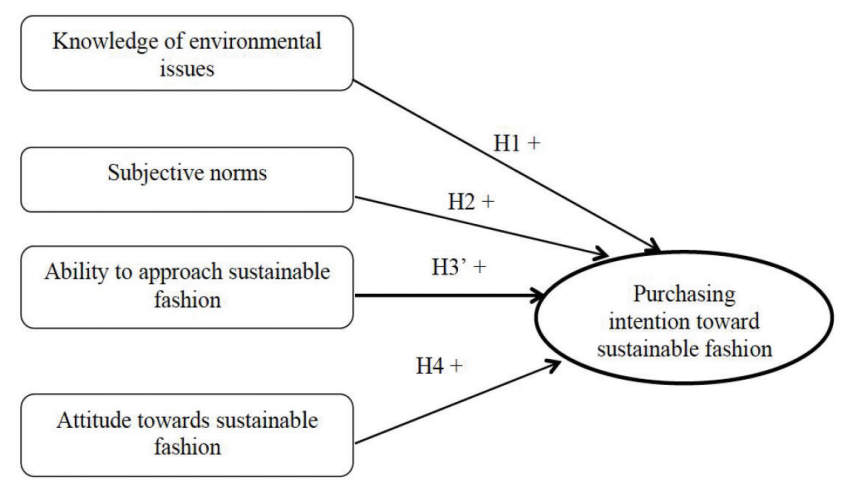

Figure 1: proposed research model

In term of the correlation analysis, the findings show the correlation with the dependent variable as all of Sig values are equal to $0.000<0.05$, Thus, suitable for regression analysis. A multivariate regression analysis is then conducted to examine the impact of 4 independent variables, containing CQ (Subjective Norms), KEI (Knowledge of environmental issues); ASF (Attitude toward sustainable fashion), AB (Ability to approach sustainable fashion) on the dependent variable PIS (Purchasing intention toward sustainable fashion).
The results show that adjusted $\mathrm{R}^{2}$ value $=0.625$, greater than $50 \%$, which means $62.5 \%$ of the variance of dependent variable is explained by independent variables, and $37.5 \%$ is explained by other absent elements in the model.

The results also point out that three variables - KEI, ASF, $\mathrm{AB}$ - have a positive impact on the variables of consumers' intention to buy sustainable fashion products. However, variable SN does not impact on consumers' intention to buy sustainable fashion products.

The ANOVA test of the four independent variables and dependent variable (PIS) shows the result with $\mathrm{F}=72.344$ and Sig. $=0.000<0.05$, hence $\mathrm{H}_{0}$ is rejected and means that the independent variables and the independent variables have a linear relationship with each other. The research model is then shown as follows: PIS $=-0.37+0.219 \mathrm{KEI}+0.70 \mathrm{ASF}+$ $0.183 \mathrm{AB}$

Therefore, the hypothesis test results are shown as below:

H1: "Consumer's knowledge of environmental issues positively affects the purchasing intention toward sustainable fashion products" is supported

H2: "Subjective norm positively affects the purchasing intention toward sustainable fashion products" is rejected

H3': 'Consumers' ability to approach sustainable fashion positively affects the purchasing intention toward sustainable fashion" is supported

H4: "The more positive attitude towards sustainable fashion a consumer has, the higher his/her purchasing intention for sustainable fashion is" is supported 
Thuy Thi Hai HO, Trinh Ngoc Phuong VU, Hieu Minh VU/

Table 4: Pearson's correlation matrix

\begin{tabular}{|l|l|c|c|c|c|c|}
\hline \multicolumn{2}{|l|}{} & SN & KEI & ASF & AB & PIS \\
\hline \multirow{2}{*}{ SN } & Pearson Correlation & 1 & 0.111 & $0.218^{* *}$ & $0.380^{* *}$ & $0.269^{* *}$ \\
\cline { 2 - 6 } & Sig. (2-tailed) & & 0.147 & 0.004 & 0.000 & 0.000 \\
\hline \multirow{2}{*}{ KEI } & Pearson Correlation & 0.111 & 1 & $0.571^{* *}$ & $.160^{*}$ & $0.554^{* *}$ \\
\cline { 2 - 6 } & Sig. (2-tailed) & 0.147 & & 0.000 & 0.036 & 0.000 \\
\hline \multirow{2}{*}{ ASF } & Pearson Correlation & $0.218^{* *}$ & $0.571^{* *}$ & 1 & $.270^{* *}$ & $0.758^{* *}$ \\
\cline { 2 - 7 } & Sig. (2-tailed) & 0.004 & 0.000 & & 0.000 & 0.000 \\
\hline \multirow{2}{*}{ AB } & Pearson Correlation & $0.380^{* *}$ & $0.160^{*}$ & $0.270^{* *}$ & 1 & $0.388^{* *}$ \\
\cline { 2 - 7 } & Sig. (2-tailed) & 0.000 & 0.036 & 0.000 & & 0.000 \\
\hline \multirow{2}{*}{ PIS } & Pearson Correlation & $.269^{* *}$ & $0.554^{* *}$ & $0.758^{* *}$ & $.388^{* *}$ & 1 \\
\cline { 2 - 7 } & Sig. (2-tailed) & $\mathbf{0 . 0 0 0}$ & $\mathbf{0 . 0 0 0}$ & $\mathbf{0 . 0 0 0}$ & $\mathbf{0 . 0 0 0}$ & \\
\hline \multirow{2}{*}{$*$ *. Correlation is significant at the 0.01 level (2-tailed). } & & & \\
\hline \multirow{2}{*}{ *. Correlation is significant at the 0.05 level (2-tailed). }
\end{tabular}

Table 5: Coefficients

\begin{tabular}{|l|c|c|c|c|c|}
\hline \multirow{2}{*}{ Model } & \multicolumn{2}{|c|}{ Unstandardized coefficients } & Standardized coefficients & \multirow{2}{*}{ t } & \multirow{2}{*}{ Sig. } \\
\cline { 2 - 5 } & B & Std. error & Beta & -1.885 & 0.061 \\
\hline (Constant) & -.370 & 0.196 & & 0.995 & 0.321 \\
\hline SN & 0.044 & 0.044 & 0.051 & 3.135 & 0.002 \\
\hline KEI & 0.219 & 0.070 & 0.179 & 1.126 & 0.000 \\
\hline ASF & 0.704 & 0.070 & 0.596 & 3.461 & 0.001 \\
\hline AB & 0.183 & 0.053 & 0.179 & \multicolumn{2}{|c|}{ Durbin - Watson $=1.365$} \\
\hline $\begin{array}{l}R^{2}=0.634 \\
\text { Adjusted } R^{2}=0.625\end{array}$
\end{tabular}

\subsection{Discussion}

With Sig. $=0.321>0.05$, the subjective norm factor is the only one among four factors that does not impact on buying intention of sustainable fashion products of people in Ho Chi Minh City. Although this finding is in contrast to the result of Weiner (2017), but it is consistent with the findings of De Lenne and Vandenbosch (2017) and Tri and Linh (2018). This can be explained by survey results conducted by Nielsen (2019) regarding the differences in consumption habits in Ho Chi Minh City and Hanoi that the difference lies in the "I" and "we" tendencies. "I" tendencies predominate in Ho Chi Minh City as consumers there are less interested in the opinions of others, but mainly based on their own needs and wants. With $\beta=0.7704$, the attitude of sustainable fashion is the strongest indicator for buying intention. The positive relationship is in line with that of previous studies (Tri \& Linh, 2018, Diddi \& Niehm, 2016; de Lenne \& Vandenbosch, 2017; Kong et al, 2016). With the regression coefficient $\beta=0.219$, the knowledge of environmental issues has the second highest regression coefficient, after the Attitude variable. While the finding does not support that of Wolsink (2007), it is in line with those of other studies (Kang et al., 2013; Diddi \& Niehm, 2016). Consumers' ability to approach sustainable fashion is a factor discovered after adjustment by Pearson model. With Sig. $=0.001$ (less than 0.05 ) and $\beta=0.183$, this factor shows the smallest impact on the intention to buy.

\section{Conclusion and Recommendation}

In term of theoretical implication, the current research applying the existing theories in domestic and foreign countries, contributes to the theoretical system regarding sustainable consumption, especially consumer buying intention for sustainable fashion products in Ho Chi Minh city, Vietnam. As regards practical implications, companies in the fashion industry, especially those which are doing 
business in sustainable products, can find some implications from the research results about factors impacting on customer buying intention, from which they can develop suitable marketing strategies to convince consumer to choose their products. The research findings suggest that, in order to influence consumers' buying intention, the firms should prioritize strategies that can improve customer attitude toward sustainable fashion, making them feel good, pleasant, satisfied and favorable when engaging in sustainable fashion consumption. Moreover, Carrigan and Attalla (2001) concludes that consumers need more information to allow them to make better ethical decisions. Mu et al. (2012) suppose that the major channels that consumers use to seek sustainable product information include public education, peer influence, and corporate marketing information about the products. They also added that public education and corporate marketing information on green consumption education is effective for improving consumers' sustainable buying intention.

Therefore, companies should increase customer knowledge of environmental issues by educating them and communicating through media, not only about the causes of environmental pollution, including manufacturing process, dye process of textile and fibers, but also about the benefits of sustainable products, including sustainable fashion. Khan et al. (2020) show that environmental knowledge can be improved by using awareness activities on sustainability issues in the University setting. The authors also suggest that increased awareness of environmental issues can change the sustainability awareness positively, which will ultimately lead to a sustainable environment. Saifullah et al. (2017) suggest that education and communication about environmental issues should focus the young generation so that it is more confident and willing to cooperate with the environmental awareness raising activities that are proposed or implemented.

Firms should also improve consumer awareness of sustainable fashion by approaching them frequently on many platforms so that information about sustainable products becomes familiar with them. The information must include the distribution addresses which should be located in online and offline places to offer convenience for customers.

In addition, customers are likely to buy sustainable fashion products even when they know it is relatively more expensive than other types of fashion products; therefore, firms should try their best to reduce the gap between prices of sustainable clothing and that of others, so that it is affordable for a wide range of consumers.

Although the literature review and research results help companies to improve their strategy to influence consumer consumption of sustainable fashion products, this study cannot avoid limitations. First, the research results show that the model of the study can only explain $63.4 \%$ of the variation in the buying intention, while there are many other factors that have not been discovered, but are likely to influence the intention to buy. Secondly, the convenient sampling method, with 172 numbers collected and used for analysis, of which the proportion of young respondents accounted for the majority, was not highly representative of the whole population. Therefore, future research should expand the research scope by investigating other factors as well as applying other sampling methods and expanding sample size for more comprehensive evaluation of the topic.

\section{References}

Ajzen, I. (1987). Attitudes, traits, and actions: Dispositional prediction of behavior in social psychology. Advances in Experimental Social Psychology, 20, 1-63.

Anh, H. (2019). Concerns on pollution from the textile industry. Retrieved from https://www.thiennhien.net/2019/09/19/noi-loo-nhiem-tu-nganh-det-may/

Bansal, P. (2002). The corporate challenges of sustainable development. Academy of Management Perspectives, 16(2), 122-131.

Boulstridge, E., \& Carrigan, M. (2000) Do consumers really care about corporate responsibility? Highlighting the attitudebehavior gap. Journal of Communication Management, 4, 355 368.

Brundtland, G. H. (1985). World commission on environment and development. Environmental Policy and Law, 14(1), 26-30.

Caniato, F., Caridi, M., Crippa, L., \& Moretto, A. (2010). Environmental sustainability in fashion supply chains: An exploratory case based research. International Journal of Production Economics, 135, 659-670.

Carrigan, M., \& Attalla, A. (2001) The myth of the ethical consumer - do ethics matter in purchase behavior? Journal of Consumer Marketing, 7, 560-574.

Chen, M. F. (2007). Consumer attitudes and purchase intentions in relation to organic foods in Taiwan: Moderating effects of food-related personality traits. Food Quality and Preference, 18(7), 1008-1021.

Chen, M. F., \& Tung, P. J. (2014). Developing an extended Theory of Planned Behavior model to predict consumers' intention to visit green hotels. International Journal of Hospitality Management, 36, 221-230.

Connell, K. Y. H. (2010). Internal and external barriers to eco conscious apparel acquisition. International Journal of Consumer Studies, 34(3), 279-286.

De Lenne, O., \& Vandenbosch, L. (2017). Fashion Media and Sustainable Fashion Buying Behavior. Journal of Fashion Marketing and Management: An International Journal, 21(4).

Diddi, S., \& Niehm, L. S. (2016). Corporate social responsibility in the retail apparel context: Exploring consumers' personal 
and normative influences on patronage intentions. Journal of Marketing Channels, 23(1-2), 60-76.

Eder-Hansen, J., Kryger, J., Morris, J., Sisco, C., \& Larsen, K. B. (2012). Engaging consumers on the sustainable consumption of fashion. Danish Fashion Institute.

Elkington, J. (2004). Enter the triple bottom line. In: A. Henriques \& J. Richardson (Eds), The Triple Bottom Line: Does It All Add up. Sterling, VA: Earth Scan.

Ellen, P. S., Wiener, J. L., \& Cobb-Walgren, C. (1991) The role of perceived consumer effectiveness in motivating environmentally conscious behavior. Journal of Public Policy \& Marketing, 10, 102-117.

Faisal, M. N. (2010). Sustainable supply chains: a study of interaction among the enablers. Business Process Management Journal, 16(3), 508-529.

Farsang, A., Gwozdz, W., Mueller, T., Reisch, L. A., \& Netter, S. (2015). Survey Results on Fashion Consumption and Sustainability Among Young Consumers in Germany, the Netherlands, Sweden, the UK and the US in 2014. Mistra Future Fashion.

Flynn, K. (2014). Textile recycling: A for-profit startup success among controversy. Retrieved from https://www.forbes.com/ sites/kerryflynn/2014/08/27/textile-recycling-a-for-profitstartup-success-among-controversy/

Gam, H. J. (2011). Are fashion conscious consumers more likely to adopt eco friendly clothing?. Journal of Fashion Marketing and Management, 15(2), 178-193.

Global Fashion Agenda. (2017). Pulse of The Fashion Industry. Retrieved from https:/globalfashionagenda.com/initiatives/ pulse/\#

Ham, M., Jeger, M., \& Frajman Ivković, A. (2015). The role of subjective norms in forming the intention to purchase green food. Economic Research-Ekonomska Istraživanja, 28(1), 738748.

Hines, J. D., \& Swinker, M. E. (1996). Consumers' willingness to purchase apparel produced from recycled fibers. Journal of Family and Consumer Sciences, 88(4), 41-44.

Hung, H. T., Quyen, H. T. T. \& Nhi, H. T. (2018). Factors impacting green consumer behavior in Hue. Hue University Journal of Science: Economics and Development, 127(5A), 199-212.

Hung, V. (2019). Textile industry reacted passively in the chemical management duty. Retrieved from https://www.vietnamplus. vn/nganh-det-may-phan-ung-rat-thu-dong-trong-cong-tacquan-ly-hoa-chat/595644.vn

Hustvedt, G., \& Dickson, M. A. (2009). Consumer likelihood of purchasing organic cotton apparel. Journal of Fashion Marketing and Management, 13(1), 49-65.

Kang, J., Liu, C., \& Kim, S. H. (2013). Environmentally sustainable textile and apparel consumption: the role of consumer knowledge, perceived consumer effectiveness and perceived personal relevance. International Journal of Consumer Studies, $37(4), 442-452$.
Khan, U., Haque, M. I., \& Khan, A. M. (2020). Environmental Sustainability Awareness in the Kingdom of Saudi Arabia. Journal of Asian Finance, Economics and Business, 7(9), 687695. https://doi.org/10.13106/jafeb.2020.vol7.no9.687

Kong, H. M., Ko, E., Chae, H., \& Mattila, P. (2016). Understanding fashion consumers' attitude and behavioral intention toward sustainable fashion products: Focus on sustainable knowledge sources and knowledge types. Journal of Global Fashion Marketing, 7(2), 103-119.

Lee, C., \& Lim, S. Y. (2020). Impact of Environmental Concern on Image of Internal GSCM Practices and Consumer Purchasing Behavior. Journal of Asian Finance, Economics and Business, 7(6), 241-254. https://doi.org/10.13106/jafeb.2020.vol7. no6.241

McKinsey. (2017). The state of fashion 2017. Retrieved from https://www.mckinsey.com/ /media/McKinsey/Industries/ Retail/Our\%20Insights/The\%20state $\% 20$ of $\% 20$ fashion/Thestate-of-fashion-2017-McK-BoF-report.ashx

Morana, R., \& Seuring, S. (2011). A three level framework for closed-loop supply chain management-linking society, chain and actor level. Sustainability, 3(4), 678-691.

Mu, J. W., Lee, S. S., \& Ryu, M. H. (2012). Consumption awareness according to information search and consumer education for green consumption: Comparative study between Korea and China. Journal of Korean Home Management Association, 30(3), 29-44.

Nguyen, P. N. D., Nguyen, V. T., \& Vo, N. N. T. (2019). Key Determinants of Repurchase Intention toward Organic Cosmetics. Journal of Asian Finance, Economics and Business, 6(3), 205-214. https://doi.org/10.13106/jafeb.2019.vol6. no3.205

Nguyen, T. K. C., Nguyen, D. M., Trinh, V. T., Tran, T. P. D., \& Cao, T. P. (2020). Factors Affecting Intention to Purchase Green Products in Vietnam. Journal of Asian Finance, Economics and Business, 7(4), 205-211. https://doi.org/10.13106/jafeb.2020. vol7.no4.205

Nielsen. (2018). Was 2018 the year of the influential sustainable consumer? Retrieved from https://www.nielsen.com/us/en/ insights/article/2018/was-2018-the-year-of-the-influentialsustainable-consumer/

Niesen. (2015). Sustainability influences purchase intent of Vietnamese consumers. Retrieved from https://www. nielsen.com/wpcontent/uploads/sites/3/2019/04/Vietnam CSR20release_EN.pdf.

Pagiaslis, A., \& Krontalis, A. K. (2014). Green consumption behavior antecedents: Environmental concern, knowledge, and beliefs. Psychology \& Marketing, 31(5), 335-348.

Paul, J., Modi, A., \& Patel, J. (2015). Predicting green product consumption using theory of planned behavior and reasoned action. Journal of Retailing and Consumer Services, 29, 123-134.

Pavlou, P. A., \& Fygenson, M. (2006). Understanding and predicting electronic commerce adoption: An extension of the theory of planned behavior. MIS Quarterly, 115-143. 
Philippe, A., \& Ngobo, P. V. (1999). Assessment of consumer knowledge and its consequences: A multi-component approach. Advances in Consumer Research, 26(1), 569-575.

Preuit, R., \& Yan, R. N. T. (2016). Fashion and sustainability: increasing knowledge about slow fashion through an educational module. Paper presented at the International Textile and Apparel Association Annual Conference Proceedings, Iowa State University Digital Press.

Sadiku, O. O. (2017). Sustainable and ethical fashion consumption: the role of consumer attitude and behavior. Hamburg School of Business Administration

Saifullah, M. K., Kari, F. B., \& Ali, M. A. (2017). Linkage between public policy, green technology and green products on environmental awareness in the urban Kuala Lumpur, Malaysia. Journal of Asian Finance, Economics and Business, 4(2), 45-53. http://dx.doi.org/10.13106/jafeb.2017.vol4.no2.45

Shen, B., Zheng, J. H., Chow, P. S., \& Chow, K. Y. (2014). Perception of fashion sustainability in online community. The Journal of the Textile Institute, 105(9), 971-979.

Singh, N. \& Gupta, K. (2013). Environmental attitude and ecological behavior of Indian consumers. Social Responsibility Journal, 9(1), 4-18.

Sparks, P., \& Shepherd, R. (1992). Self-Identity and the Theory of Planned Behavior: Assessing the role of identification with "Green Consumerism". Social Psychology Quarterly, 55(4), 388-399.

Suki, N. M. (2016). Green product purchase intention: impact of green brands, attitude, and knowledge. British Food Journal, 118(12), 2893-2910.

Tabachnick, B. G., \& Fidell, L. S. (2007). Using multivariate statistics. Boston, MA: Pearson.
Tri, C. M., \& Linh, N. K. (2018). Buying intention toward green fashion in Ho Chi Minh City. Industry and Trade magazine. Retrieved from http://tapchicongthuong.vn/bai-viet/y-dinhtieu-dung-san-pham-thoi-trang-xanh-tai-thanh-pho-ho-chiminh-54481.htm

United Nations. (2019). UN launches drive to highlight environmental cost of staying fashionable. Retrieved from https://news.un.org/en/story/2019/03/1035161

Vermeir, I., \& Verbeke, W. (2008). Sustainable food consumption among young adults in Belgium: Theory of planned behavior and the role of confidence and values. Ecological Economics, 64(3), 542-553.

Weiner, H. E. (2017). Wearing your Ethics: Investigating Consumer Purchase Intention of Ethically Produced Fashion Products. Master's thesis of University of South Carolina. Retrieved from https://scholarcommons.sc.edu/etd/4351.

Wolsink, M. (2007). Wind power implementation: the nature of public attitudes: equity and fairness instead of 'backyard motives. Renewable and Sustainable Energy Reviews, 11(6), 1188-1207.

Yadav, R., \& Pathak, G. S. (2016). Young consumers' intention towards buying green products in a developing nation: Extending the theory of planned behavior. Journal of Cleaner Production, 135, 732-739.

Yamoah, F. A., Duffy, R., Petrovici, D., \& Fearne, A. (2016). Towards a framework for understanding Fairtrade purchase intention in the mainstream environment of supermarkets. Journal of Business Ethics, 136(1), 181-197.

Yang, C. L., Lin, S. P., Chan, Y. H., \& Sheu, C. (2010). Mediated effect of environmental management on manufacturing competitiveness: an empirical study. International Journal of Production Economics, 123(1), 210-220. 